\title{
Effectiveness of Learning Materials with Science- Philosophy Oriented to Reduce Misconception of Students on Chemistry
}

\author{
Afadil \\ Chemistry Education Study Program \\ Universitas Tadulako \\ Palu, Indonesia
}

\author{
Anang WM Diah \\ Chemistry Education Study Program \\ Universitas Tadulako \\ Palu, Indonesia \\ anangwmdiah@gmail.com
}

\begin{abstract}
Students' understanding which is not consistent with scientific conceptions or what is universally accepted can be categorized as misconceptions. Some misconceptions in Chemistry have been investigated in previous studies. Misconception can be contributed by the abstract nature of the concepts, imparted by teachers or preconceived beliefs by students. The aim of this study was to provide a valid, practical, and effective learning materials of Chemistry with sciencephilosophy oriented to reduce misconception of students on Chemistry. This study applied Research and Development $(R \&$ D) design through the development of learning materials with the 4D (define, design, develop, and disseminate) model. Effectivity of the learning materials was assessed by observers and tested to 44 students on the topic of Salt Hydrolysis. The results showed that the developed learning materials reduced misconceptions of science students in grade eleventh from a public senior high school in Indonesia from an average of $53.9 \%$ to $19.6 \%$, or decreased misconception by $34.3 \%$. These results indicated that the developed learning materials with science-philosophy oriented were effective in accordance with the purpose of development. These were expected to contribute to improving the quality of learning by reducing misconception of students on Chemistry.
\end{abstract}

Keywords-learning materials, science-philosophy, misconception

\section{INTRODUCTION}

Chemistry is regarded as a difficult subject by majority students [1], and $68 \%$ of students still argue their difficulties in a recent study [2]. Learning matter in Chemistry requires good understanding and skill of several concepts and transition between micro, macro, and symbolic representations [3], [4]. Students have to struggle to learn those concepts in chemistry. Many of them gained the target, but some of them also unsuccessful. Therefore, understanding the theoretical content of chemistry is best learned as set models. These models play a major role in all science disciplines, and they are also as part of the problem of students for understanding chemistry. A model is produced to enable the phenomenon to be explained clearer in terms of the theory [5].
Chemistry is generally acquired and developed based on experiments involving skill and reasoning in finding the answer to the question of what, how, and to what natural phenomena, especially with regard to the composition, structure, properties, transformation, dynamics, and energetics substance. It concerns with the properties and reactions of substances [4]. These properties explain some aspects of the nature of the bonding between aggregation particles in those substances, whether they are in solid, liquid, or gas at a given temperature and pressure. Viewing from the side of the philosophy of science, the concepts in the sciences (including chemistry) refers to the three questions, which related to aspects of ontology, epistemology, and axiology. This suggests that in order to understand and solve problems in chemistry, students are required in-depth study of the chemistry concept in learning.

Many students met difficulties with abstract concepts in chemistry, and these correlated to their misconceptions due to information and models presented in previous study unprepared to describe or understand enough [6]. Some studies have shown that misconceptions in chemistry are constructed in different areas not only for high school students but also for universities students. Some of them are introductory concepts [7], atomic structure [8], chemical bonding [2], [9-12], chemical equilibrium and chemical reactions [13-15], electrochemistry [16], [17], Organic alkenes [18], oxidation and reduction [19], acids-bases, and solutions [20], [21]. Most of these misconceptions topics are also found in pre-university students [22].

Based on their understanding of a concept, a number of people can be grouped into three: those who know the concept $(\mathrm{KC})$, do not know the concept (DKC), and misconceptions (MC). In this paper, misconceptions can be defined as students' understanding which is not consistent with scientific conceptions or any concept that differs from the universally accepted scientific understanding of the term to date [10], [14], [23].

Since students learn chemical concepts, their constructions of understanding on the concepts sometimes differ from that 
the instructors hold and has tried to present. The study also indicates that advanced study does not always result in better understanding of basic concepts in chemistry [16]. Misconception can be contributed by the abstract nature of the concepts, imparted by teachers or preconceived beliefs by students [14], [24]. If the instructors do not clearly explain the concepts, students' misconceptions may happen and remain during their advanced study of chemistry. The misconceptions based on intuitive notions need more reasonable ways to be accepted as a new concept, whether misconceptions from the previous teaching can be planned by different teaching [24]. However, the study also found that misconceptions are not only students, but Chemistry teachers also have to be addressed with these misconceptions [13-15]. Teachers should have the ability to offer students with correct information and helpful examples, they must also be able to guide students on the reasoning process [5].

The phenomenon of misconceptions on pupils, students, teachers or anyone else should not be allowed on learning subjects because the misconceptions might become an obstacle for future understanding concepts [5], [10], [23]. Misconceptions must be reduced with the right conceptual change [25]. Misconceptions, in general, could be overcome by: (1) understanding students' misconceptions, (2) trying to find the source of these misconceptions, and (3) finding an appropriate treatment to overcome these misconceptions [26]. The basic reasons for students' misconceptions in learning chemistry are students obtained the concept not properly understand, and they are not optimal in achieving a higher order of thinking skills (HOTS) level. Students should be trained to understand the basic problems and improve their higher order thinking skills. However, students and their education institutions lived in different worlds which then affect to their difficulties in learning chemistry [1]. In this situation, students thought that fulfilling their tasks and sitting in the class were more important, whereas institution thought that students' interest in the subject was more important. Assessing the concepts help students philosophically to understand more deeply, so the concepts will be more meaningful, hence the students will enable to associate and understand natural phenomena correlated to their learning concepts [27].

In our previous report, the low-level understanding of chemical concepts influenced significantly to the students' achievement on Thermochemistry at Universitas Tadulako, Palu [28]. The study found misconceptions on this topic up to $73.5 \%$ responses. The students have not been able to connect between the chemistry concepts with the philosophical aspects of science. This paper is an attempt to develop valid, practical and effective learning materials of chemistry to reduce students' misconceptions by delivering topics with science philosophy oriented and to overcome the difficulties of teachers in teaching chemistry concepts. More specifically the purpose of this paper is to gain a better understanding of the science secondary school students in Palu on the topic Salt Hydrolysis.

\section{METHOD}

This study applied a research and development (R \& D) design through the development of learning materials with the 4D (define, design, develop, and disseminate) model [29]. The study started with a preliminary study, need assessment, student analysis, and subsequently the outcome of learning materials which have been tested its feasibility. Learning materials (lesson plans, worksheets, student books, and instrument for misconceptions or concepts understanding test) which have been developed based on verification from the expert's team. All learning materials are validated to determine their feasibility.

The effectiveness of the learning materials of Salt Hydrolysis was assessed by observers and tested to 44 science students in grade eleventh from a public senior high school in Indonesia. The instruments for student's achievement (pre-test and post-test) utilize the Certainty of Response Index (CRI) in conjunction with answers to multiple choice questions modified from the previous study [30] as presented in Table I.

TABLE I. RATING AND CATEGORY CONCEPTION STUDENTS

\begin{tabular}{|l|l|}
\hline Rating & \multicolumn{1}{c|}{ Category } \\
\hline 0 & $\begin{array}{l}\text { Totally guessed Answer: If you answered about 100\% to predict } \\
\text { or guess completely. }\end{array}$ \\
\hline 1 & $\begin{array}{l}\text { Almost a guess: If in answering questions guesses element } \\
\text { percentage between 75\% -99\% or almost guess. }\end{array}$ \\
\hline 2 & $\begin{array}{l}\text { Not Sure: If in answering questions percentage guesses element } \\
\text { between 50\% -74\% or unsure. }\end{array}$ \\
\hline 3 & $\begin{array}{l}\text { Sure: If in answering questions percentage guesses element } \\
\text { between 25\% -49\% or confident. }\end{array}$ \\
\hline 4 & $\begin{array}{l}\text { Almost Certain: If the answer the riddle element percentage } \\
\text { between 1\% and 24\%, or almost certain. }\end{array}$ \\
\hline 5 & $\begin{array}{l}\text { Certain: If in answering questions is no element of guesswork at } \\
\text { all (0\%) or definitely. }\end{array}$ \\
\hline
\end{tabular}

Decision matrix for an individual student and for a given question was analyzed using the matrix in Table II. Matrix was derived from the answer of the student based on combinations of a correct or wrong answer and of low or high CRI [1].

TABLE II. DECISION MATRIX FOR AN INDIVIDUAL STUDENT BASED ON COMBINATIONS OF CORRECT OR WRONG ANSWER AND LOW OR HIGH CRI.

\begin{tabular}{|l|l|l|}
\hline Criteria Answer & \multicolumn{1}{|c|}{ Low CRI (<2.5) } & \multicolumn{1}{|c|}{ High CRI (> 2.5) } \\
\hline \multirow{4}{*}{ Correct answer } & $\begin{array}{l}\text { Correct answer and low } \\
\text { CRI }\end{array}$ & $\begin{array}{l}\text { Correct answer and high } \\
\text { CRI }\end{array}$ \\
\cline { 2 - 3 } & $\begin{array}{l}\text { Lack of knowledge } \\
\text { (lucky guess) }\end{array}$ & $\begin{array}{l}\text { Knowledge of correct } \\
\text { concepts }\end{array}$ \\
\hline \multirow{3}{*}{ Wrong answer } & $\begin{array}{l}\text { Wrong answer and low } \\
\text { CRI }\end{array}$ & $\begin{array}{l}\text { Wrong answer and high } \\
\text { CRI }\end{array}$ \\
\cline { 2 - 3 } & Lack of knowledge & Misconceptions \\
\hline
\end{tabular}

Identification of individual misconceptions is intended to determine the percentage of students experiencing misconceptions on a given set of concepts. Percentage of calculation is determined from the number of students experiencing misconception divided by the total students. Identification of group misconceptions is intended to find out which concept with high misconception among other concepts. Each group is determined by scores of the average 
CRI of correct students' answer (CRIC), the average CRI of wrong students' answer (CRIW), and the fraction of students who answered correctly $(\mathrm{Fc})$. CRIC score is obtained from the number of CRI students who answered correctly divided by the total students who answered correctly. CRIW score is obtained from the number of CRI students who answered wrong divided by the total students who answered wrong. While Fc is obtained from the total students who answered correct divided $100 \%$ [2].

Data are then analyzed using descriptive statistics in the form of tables, percentages, and charts. The results of data analysis are discussed narratively by comparing the results with the theory.

\section{RESULTS AND DISCUSSIONS}

\section{A. Chemistry Learning with Science-Philosophy Oriented}

This study applied with emphasizing aspects of sciencephilosophy. Understanding concepts of chemistry involve a complex series of intellectual activities through observing phenomena, studying facts, understanding models and theories, developing reasoning skills, and testing epistemology chemistry [32]. This will improve students' understanding of the concept of chemistry during the learning process. Aspects of science-philosophy include three fundamental questions which are related to aspects of ontology, epistemology, and axiology. These aspects discuss reality or the truth of a fact, the methods used to gain knowledge, and a theory of values relating to the usefulness of a knowledge [33].

Indicators of implementation and quality of learning in this study were monitored from the implementation of syntax in the lesson plan and students' activities during the learning process. The implementation of syntax in lesson plan was assessed by experts. The results showed that all stages were implemented with a good category. In implementing lesson plan, teachers need to have a clear and comprehensive view of the nature of the topic in general. They also need to know the way of students to construct their mental, to express it constructively in the class, to introduce scientifically in the class, and to develop and conduct good teaching activities effectively in the class [4]. Chemistry teachers need to emphasize the transition from macroscopic to microscopic, and they should use models such as concrete models, analogical models, theoretical models and simulations to make concepts more understandable [5].

Students' activities during learning process were assessed based on the affective and psychomotor aspects of students, in addition to the cognitive aspects through the test. The affective aspects assessed their ability to give argumentation, honesty, and cooperation. All aspects observed showed good and excellent categories. The most prominent affective assessment was the ability to argue in discussion session based on their observations. This showed the students' enthusiasm and honesty during the learning process. The psychomotor aspect was assessed including the skill of measuring the solution using a measuring tube, pipetting the solution, and reading the $\mathrm{pH}$ solution using universal indicator. The results showed that all aspects observed were categorized as good and excellent categories.

\section{B. Classification of Students' Conception on Salt Hydrolysis}

Students' conceptions are classified into categories of "know concept" (KC), "do not know concept" (DKC), and "misconception" (MC). These classifications are based on the pretest on each objective concept representing the concept of Salt Hydrolysis. The data of percentage students for those classifications are presented in Fig. 1 and Fig. 2. These Fig.s show that all nine concepts tested indicate individuals misconceptions, and the majority of students $(>50 \%)$ have the misconception in the concept number of 4 to 9 . Overall concepts contribute to $53.9 \%$ of students' misconception, and the data show that only $18.9 \%$ students know concepts.

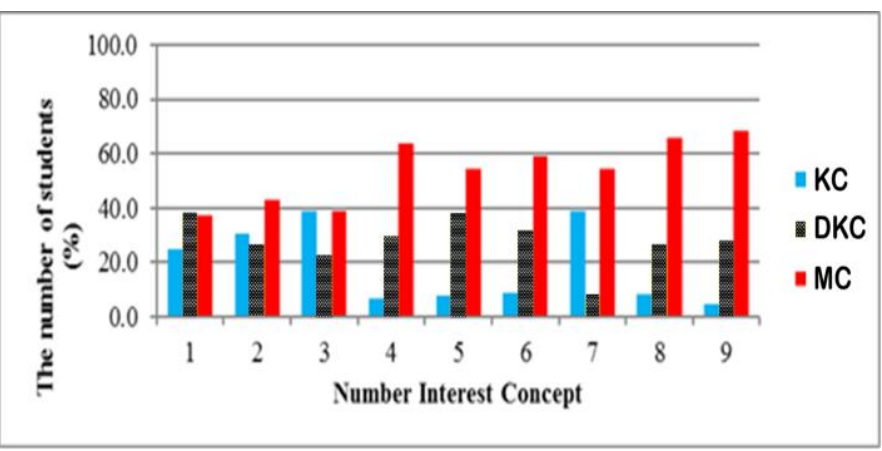

Fig. 1. Percentage of students in $\mathrm{KC}$, DKC, and MC categories per interest concept taken prior implementing learning with science-philosophy oriented

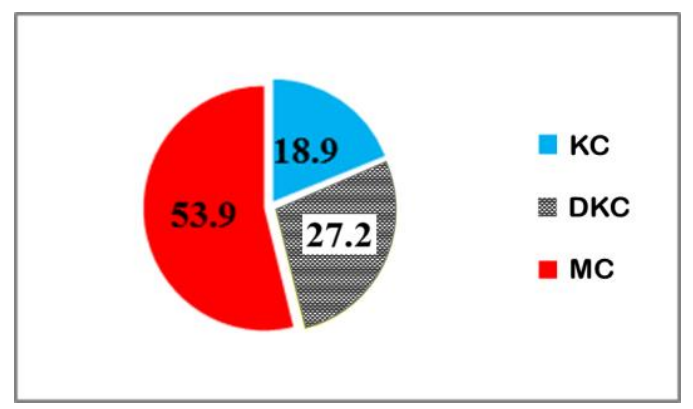

Fig. 2. Percentage of students in KC, DKC, and MC categories for overall interest concepts prior implementing learning with science-philosophy oriented

Identification of misconceptions is used to assign the most alleged concept to contribute to the misconception from the 9 concepts on Salt Hydrolysis to be tested. This identification is based on the data of CRIC, CRIW, and Fc for each item representing concepts on Salt Hydrolysis. Data of CRIC, CRIW, and Fc are calculated based on pretest analysis and those presented in Fig. 3. This Fig. indicates that misconceptions occur if the average value of CRIW is in $2.5<$ $\mathrm{CRIW} \leq 5$, and $\mathrm{Fc}<0.5$. Fig. 3 confirms that students' misconception occurred on each concept tested. All concepts have a CRIW score $>2.5$, and most of them with $\mathrm{Fc}<0.5$ occurred students' misconceptions unless the concept number 1 and 3 which have a weak impact on students' misconceptions.

Fig. 3 also shows the occurrence of misconceptions $77.8 \%$ (7 of 9 number interest concepts) on Salt Hydrolysis indicates most of the students have not been able to construct their knowledge in understanding the concepts, even though they 
have learned solutions and acid-base reactions. Different understanding of students in terms of processing information to the concept can be associated with the structure of knowledge constructed by the individual to understand and explain their experiences [34]. Therefore, failure in applying learning process will contribute to the students' misconceptions.

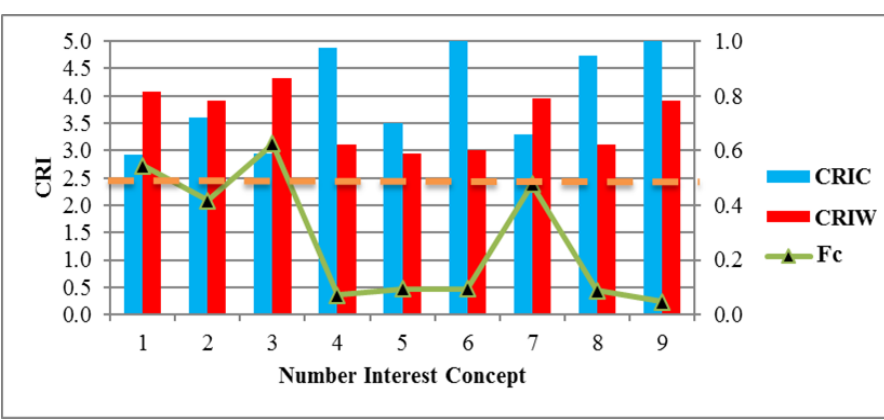

Fig. 3. Graphic of CRIC, CRIW, and Fc based on each interest concept on salt hydrolysis prior implementing learning with science-philosophy oriented.

Fig. 4 and Fig. 5 show the percentage of students with $\mathrm{KC}$, $\mathrm{DKC}$, and $\mathrm{MC}$ categories after the implementation of the learning materials with science-philosophy oriented. These data were taken by post-test after closing the learning process. The learning process increase conceptions of students into $\mathrm{KC}$ by $65.0 \%$ (improve $46.1 \%$ ), and decrease $11.8 \%$ of DKC and $34,3 \%$ of $\mathrm{MC}$ from $27.2 \%$ to $15.4 \%$, and from $53.9 \%$ to $19.6 \%$, respectively.

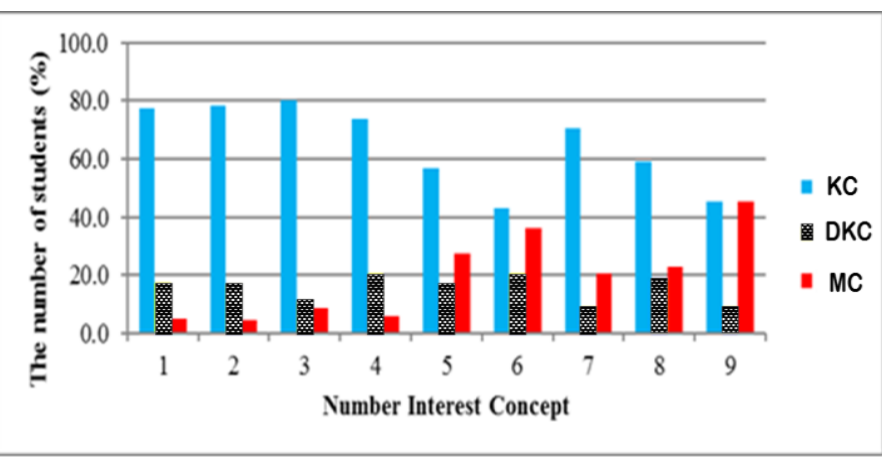

Fig. 4. Percentage of students in $\mathrm{KC}, \mathrm{DKC}$, and $\mathrm{MC}$ categories per interest concept taken after implementing learning with science-philosophy oriented.

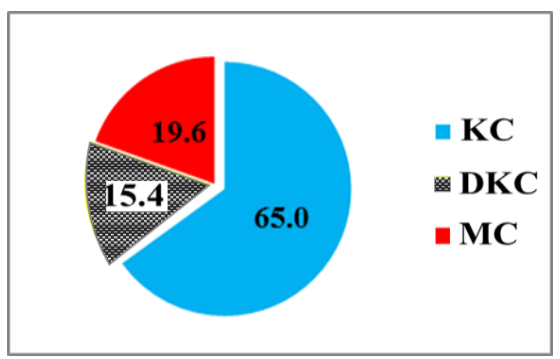

Fig. 5. Percentage of students in KC, DKC, and MC categories for overall interest concepts after implementing learning with science-philosophy oriented.

Data of CRIC, CRIW, and Fc after implementing learning with science-philosophy oriented are calculated from the posttest results and presented in Fig. 6. There are 7 concepts without misconceptions, and two concepts are still in the misconceptions with weak impact category. Their CRI scores are close to 2.5 , and the correct fraction $(\mathrm{Fc})$ score is close to 0.5. In summary, the percentage ratio of students with misconceptions on the pre-test and post-test are presented in Table III

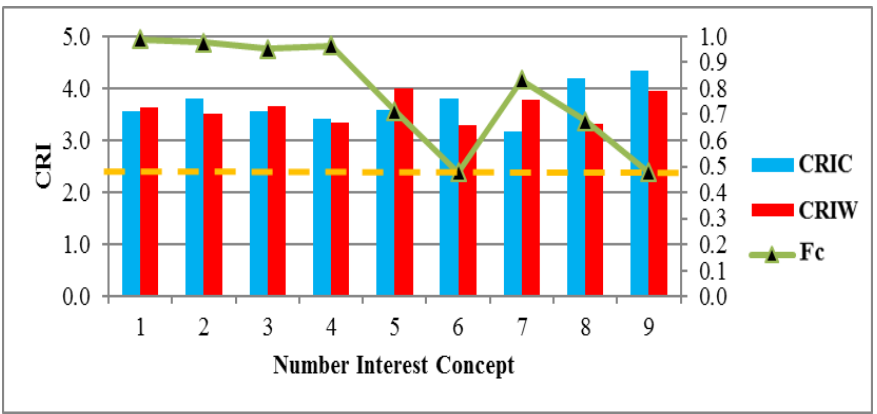

Fig. 6. Graphic of CRIC, CRIW, and Fc based on each interest concept on Salt Hydrolysis after implementing learning with science-philosophy oriented.

\section{TABLE III. PERCENTAGE OF STUDENTS' MISCONCEPTION} ANALYZED FROM PRETEST AND POSTTEST

\begin{tabular}{|c|c|c|c|c|}
\hline \multirow{2}{*}{ No } & \multirow{2}{*}{ Objective Concept } & \multicolumn{3}{|c|}{ Misconception $(\%)$} \\
\hline & & Pretest & Posttest & Reduction \\
\hline 1 & $\begin{array}{l}\text { Identifying characteristics of } \\
\text { some types of salt that can be } \\
\text { hydrolyzed. }\end{array}$ & 37.1 & 4.9 & 32.2 \\
\hline 2 & $\begin{array}{l}\text { Identifying characteristics of } \\
\text { some types of salt that cannot } \\
\text { be hydrolyzed in water through } \\
\text { experimentation. }\end{array}$ & 43.2 & 4.5 & 38.7 \\
\hline 3 & $\begin{array}{l}\text { Identifying saline solution } \\
\text { which undergoes hydrolysis in } \\
\text { part of the nature of the } \\
\text { solution. }\end{array}$ & 38.6 & 8.6 & 30.0 \\
\hline 4 & $\begin{array}{l}\text { Comparing the } \mathrm{pH} \text { of some } \\
\text { saline solution derived from a } \\
\text { weak acid and a strong base }\end{array}$ & 63.6 & 5.7 & 57.9 \\
\hline 5 & $\begin{array}{l}\text { Comparing the } \mathrm{pH} \text { of some } \\
\text { saline solution derived from a } \\
\text { strong acid and a weak base }\end{array}$ & 54.5 & 27.3 & 27.2 \\
\hline 6 & $\begin{array}{l}\text { Comparing the } \mathrm{pH} \text { of some } \\
\text { saline solution derived from a } \\
\text { weak acid and a weak base }\end{array}$ & 59.1 & 36.4 & 22.7 \\
\hline 7 & $\begin{array}{l}\text { Comparing the } \mathrm{pH} \text { of some } \\
\text { saline solution derived from a } \\
\text { strong acid and a strong base }\end{array}$ & 54.5 & 20.5 & 34.0 \\
\hline 8 & $\begin{array}{l}\text { Determining the } \mathrm{pH} \text { of the } \\
\text { saline solution based on } \\
\text { hydrolysis reaction }\end{array}$ & 65.9 & 22.7 & 43.2 \\
\hline 9 & $\begin{array}{l}\text { Determining the mass of salt } \\
\text { which hydrolyzed at a certain } \\
\text { pH }\end{array}$ & 68.2 & 45.5 & 22.7 \\
\hline & Average & 53.9 & 19.6 & 34.3 \\
\hline
\end{tabular}

Pretest scores in Table III indicate aspects of initial knowledge or students' misconceptions. However, post-test scores obtained by students describe learning achievement of students after joining learning process using the developed learning materials. This table shows reducing the average percentage of misconceptions of $34.3 \%$ from $53.9 \%$ to $19.6 \%$ for all concepts after implementation of learning materials with science-philosophy oriented. This is in line that combining active work to foster personal experience through 
learning materials with science-philosophy oriented improve conceptual understanding in learning [35]. The occurrence of misconceptions on certain concepts is a fairness because preventing students' misconception is also hard. Many different backgrounds contributed to students' misconception in learning topics, and they are well documented in the literature [11], [14], and references therein.

\section{CONCLUSION}

Learning materials with science-philosophy oriented have been implemented to science students in grade eleventh from a public senior high school in Palu, Indonesia. The learning materials on the topic of Salt Hydrolysis reduced students' misconception about $34 \%$ from an average of $53.9 \%$ to $19.6 \%$. This result indicates that the learning materials with sciencephilosophy oriented are effective in accordance with the purpose of the development.

\section{ACKNOWLEDGMENT}

The authors would like to express their thank to Universitas Tadulako by providing research funding through DIPA, Directorate of Research and Community Service (DRPM), The Ministry of Research, Technology, and Higher Education of the Republic Indonesia in 2015.

\section{REFERENCES}

[1] C.S. Carter, N.W. Brickhouse, What makes chemistry difficult? Alternate perceptions, Journal of Chemical Education, 66 (1989) 223.

[2] E. Gudyanga, T. Madambi, Students' Misconceptions about Bonding and Chemical Bonding Structure in Chemistry, The Dyke, 8 (2014) 24-40.

[3] A.H. Johnstone, Why is science difficult to learn? Things are seldom what they seem, Journal of Computer Assisted Learning, 7 (1991) 75-83.

[4] T. Levy Nahum, A. Hofstein, R. Mamlok-Naaman, Z. Bar-Dov, Can Final Examinations Amplify Students' Misconceptions In Chemistry?, Chemistry Education: Research And Practice, 5 (2004) 301-325.

[5] E. Gudyanga, Anthropomorphic notion of atoms, the etiology of pedagogical and epistemological learning proactive interference among Chemistry learners Implications, Science Journal of Education, 2 (2014) 65-70.

[6] C. Horton, Student Alternative Conceptions in Chemistry, California Journal of Science Education, 7 (2007).

[7] A. Ayas, A. Demirbas, Turkish Secondary Students' Conceptions of the Introductory Concepts, Journal of Chemical Education, 74 (1997) 518.

[8] C. Stefani, G. Tsaparlis, Students' levels of explanations, models, and misconceptions in basic quantum chemistry: A phenomenographic study, Journal of Research in Science Teaching, 46 (2009) 520-536.

[9] H.S. Dhinsda, D.F. Treagust, Conceptual Understanding of Bruneian Tertiary Students: Chemical Bonding and Structure, Brunei International Journal of Science and Mathematics Education, 1 (2009) 33-51.

[10] S. Ünal, Costu, B., and Ayas, A., Secondary School Students Misconceptions of Covalent Bonding, Journal of Turkish Science Education, 7 (2010) 4-29.

[11] K.S. Taber, Models, Molecules and Misconceptions- A Commentary on Secondary School Students' Misconceptions of Covalent Bonding, Journal of Turkish Science Education, 8 (2011) 3-18.

[12] K.V.F. Fatokun, Instructional Misconceptions Of Prospective Chemistry Teachers In Chemical Bonding, International Journal of Science and Technology Educational Research, 7 (2016) 18-24.

[13] D. Cheung, H.-j. Ma, J. Yang, Teachers' Misconceptions about the Effects of Addition of More Reactants or Products on Chemical Equilibrium, International Journal of Science and Mathematics Education, 7 (2009) 1111-1133.
[14] C.K. Chu, K.Y. Hong, Misconceptions in the teaching of chemistry in secondary schools in Singapore \& Malaysia, Innovative Thoughts, Invigorating Teaching Sunway University College Swan Convention Centre, Bandar Sunway, 2010, pp. 1-10.

[15] A. Kolomuç, S. Tekin, Chemistry Teachers' Misconceptions Concerning Concept of Chemical Reaction Rate, Eurasian Journal of Physics and Chemistry Education, 3 (2011) 84-101.

[16] H.S. Lin, T.C. Yang, H.L. Chiu, C.Y. Chou, Students' Difficulties in Learning Electrochemistry, Procedia National Science Council, 12 (2002) 100-105.

[17] A.R. Ozkaya, M. Uce, M. Şahin, Prospective Teachers' Conceptual Understanding of Electrochemistry: Galvanic and Electrolytic Cells, University Chemistry Education, 7 (2003) 1-12.

[18] G. Sendur, Prospective Science Teachers' Misconceptions in Organic Chemistry: The Case of Alkenes, Journal of Turkish Science Education, 9 (2012) 186-190.

[19] H.D. Barke, A. Hazari, S. Yitbarek, Misconceptions in Chemistry: Addressing Perceptions in Chemical Education, Springer-Verlag, Berlin, Heidelberg, 2009.

[20] M. Kousathana, M. Demerouti, G. Tsaparlis, Instructional Misconceptions in Acid-Base Equilibria: An Analysis from a History and Philosophy of Science Perspective, Science \& Education, 14 (2005) 173-193.

[21] J.W. Lin, M.H. Chiu, J.C. Liang, Exploring Mental Models and Causes of Students'Misconceptions in Acids and Bases., the NARSTVancouver, Canada, 2004.

[22] S.M. Al-Balushi, A.K. Ambusaidi, A.H. Al-Shuaili, N. Taylor, Omani Twelfth Grade Students' Most Common Misconceptions in Chemistry, Science Education International 23 (2012) 221-240.

[23] M.B. Nakhleh, Why some students don't learn chemistry: Chemical misconceptions, Journal of Chemical Education, 69 (1992) 191.

[24] K.S. Taber, Chemical Misconceptions - Prevention, Diagnosis, and Cure: Theoretical Background, Royal Society of Chemistry, London, 2002.

[25] R.W. Dahar, Teori-Teori Belajar, Ditjen Dikti-P2LPTK, Jakarta, 2011.

[26] P. Suparno, Miskonsepsi dan perubahan konsep dalam pendidikan fisika, Cet. 2 ed., Jakarta : Grasindo2013.

[27] Effendy, Pembelajaran Kimia Secara Mendasar untuk Menjawab Tantangan dan Memenuhi Harapan Kurikulum 2013, Seminar Nasional Kimia \& Pendidikan Kimia UNG 2014, UNG Gorontalo, Gorontalo, 2014.

[28] Afadil, Kajian Problem Solving dalam Pembelajaran Kimia Melalui Aspek Epistemologi Sains untuk Menumbuhkan Kemampuan Berpikir Kritis Mahasiswa, Seminar Nasional Kimia \& Pendidikan Kimia ung 2014, UNG Press, Gorontalo, 2014, pp. 199-207.

[29] S. Thiagarajan, D.S. Semmel, M.I. Semmel, Instructional Development for Training Teachers of Exceptional Children: A Sourcebook, Leadership Training Institute/Special Education, University of Minnesota1974.

[30] S. Hasan, D. Bagayoko, E.L. Kelley, Misconceptions and the Certainty of Response Index (CRI), Physics Education, 34 (1999) 294.

[31] M.A. Thohir, Pembelajaran Guided Discovery Dalam Upaya Remediasi Miskonsepsi Materi Listrik Dinamis Calon Guru, Lensa, 3 (2015) 255264.

[32] H. Achmad, L. Baradja, Demonstrasi Sains Kimia Jilid 2: Kimia Deskriptif Melalui Demo Kiimia, Nuansa, Bandung, 2012.

[33] J.S. Suriasumantri, Filsafat Ilmu Sebuah Pengantar Populer, Sinar Harapan, Jakarta, 2013.

[34] S. Sen, A. Yilmaz, The Effect of Learning Styles on Student's Misconceptions and Self-efficacy for Learning and Performance, Procedia - Social and Behavioral Sciences, 46 (2012) 1482-1486.

[35] G. Lawrie, E. Bartle, Chemistry vlogs: a vehicle for student-generated representations and explanations to scaffold their understanding of structure-property relationships, international Journal of Innovation in Science and Mathematics Education (formerly CAL-Laborate International), 21 (2013) 27-45 